\title{
Diabetes and arterial hypertension resorts of treatments and plants used for their treatments in three phytogeographic areas of
} Cameroon

\author{
Tsabang Nole*1, Tsambang Djeufack Wilfried Lionel2, Ndikum Valentine Nchafor3, \\ Tsambang Fokou Stheve Cedrix4 and Donfack Delphine5
}

1- Institute of Medical Researches and Studies of Medicinal Plants-Yaounde, Cameroon. 2- High Institute of Medical Technology, Yaounde, Cameroon. 3- University of Yaounde 1, Faculty of Medicine and Biomedical Sciences, Yaounde, Cameroun 4- Fine arts Institute, Foumban, Department of Architecture, University of Dschang, Cameroon 5- University of Yaounde 1, Faculty of Specialized Education, Cameroon

\section{ABSTRACT}

There are three principal resorts of diseases' treatment in Africa that include the mixed traditional and conventional medicine, the pure traditional medicine and the pure conventional medicine. The objective of this study was to determine the importance of resorts of treatment for selecting efficacious medicinal plants used for the management of diabetes and/or arterial hypertension in Cameroon. The resorts of diabetes and/or arterial hypertension treatment preferred by 1131 Cameroonians, selected in 58 socio-cultural groups and plants used were evaluated. This sample of interviewees was distributed as follow: 293 in coastal dense humid rain forests (phytogeographic area 1), 577 in continental dense humid rain forests (phytogeographic area 2) and 561 in Guinean and Soudano-Zambesian savannahs (Phytogeographic area 3). The combination of traditional and conventional medicine was the most favorable therapeutic resort of diabetes and/or arterial hypertension treatment $(58,89 \%)$, following by pure traditional medicine $(38,72 \%)$ and pure conventional medicine $(2,39 \%)$. These main resorts present manifold variances in many social groups including. The more important variances include Self herbal medication and consultation of traditional healers $(21,75 \%)$; self herbal medication and consultation of medical doctors $(33,08 \%)$; traditional healers, self herbal medication and consultation of medical doctors $(22,64 \%)$. The percentages in brackets correspond to the proportion of interviewees recorded. The interviewees who preferred traditional medicine know more available and efficacious medicinal plants. Therefore with their aid 33 plants which relieve the health condition of some diabetic and/ or hypertensive suspected or indirect and confirmed patients were recorded. The most important of these plants that include Azadirachta indica, Momordica charantia, Phyllanthus amarus, Phyllanthus niruri, Laportea ovalifolia, Ceiba pentandra, Allium cepa, Persea americana and Catharanthus roseus relieve the followed up diabetic with hypertension patients. These plants revealed interesting for the potential management of diabetes and hypertension. Meanwhile the recorded plants needed to be detailed investigated for their chemical and pharmacological properties necessary for drugs discovery.

\section{Keywords:}

Diabetes and arterial hypertension, preferred resorts of their treatment, usual plants, indigenous people, Cameroon

*Correspondence to Author: Tsabang Nole, Institute of Medical Researches and Studies of Medicinal Plants-Yaounde, Cameroon.tsabang2001@yahoo.fr or tsabang@ hotmail.com; Telephone (237 677 $461631)$

\section{eSciencePublisher} eSciPub LLC, Houston, TX USA. Website: http://escipub.com/ 


\section{Introduction}

The resorts of diseases' treatments depend on the culture, the academic standard, the geographical situation of the residence of people, the standard of living, the matrimonial status, the type of profession, the age brackets of people, the type of disease and the patient condition. It is also linked to the frequency of the disease (Regroupement québécois des maladies, 2004). Therefore the study was aimed at determining the importance of resorts of treatment for selecting efficacious medicinal plants used for the management of diabetes and/or arterial hypertension in Cameroon. The main reason for indigenous people to choice a pure traditional medicine is the knowledge of medicinal plants or the present of a relative traditional healer. People who preferred pure traditional medicine can provide important information about medicinal plants. The traditional medicine such as it is practiced nowadays, reveals that it not like someone believe, hermetically sealed, congeal, in time and in the space.

Today, a vast store of knowledge concerning therapeutic properties of medicinal plants has accumulated through either experiences or knowledge evolved and transferred to the generation of tribal people, traditional healers or practitioners (Lokondo Mozouloua D. 2004). But interviewees need strategic methods to follow them before identifying who among the population is a potential older of good information. The medicine needs new drugs for the management of diabetes and hypertension. The progression of the resistance to medicines is partially the result of their bad use that has rendered useless several antibiotics and other drugs that save life. These two tendencies explain the necessity for researchers and pharmaceutical companies for urgently looking for new sources of treatments, which are oriented more and more throughout the traditional medicine (Priya Shetty 2010); UN Economic and Social Council, 2009; WHO, 2007).

\section{Material and methods}

Detailed traditional resorts of treatment and ethnopharmacological thorough herbal medicine preparation

The survey was conducted nearby 1131 infor- mants from 58 tribes of Cameroon, in a random distribution. Folklore and modern medical information on diabetes and arterial hypertension' resorts of treatments were recorded during interviews and discussions, following a semi-structured ethnopharmacological detailed methodology developed in Tsabang N. et al. 2015a. Samples of recorded usual plants were collected, dried, identified and confirmed at National Herbarium of Cameroon, and conserved in the Institute of Medical Research and Medicinal Plants Studies.

\section{Distribution of interviewees}

The 1131 interviewees are distributed as follow, according to some social characters: from their environment: 301 city-dwellers and 830 villagers; from academic standard: 727 illiterates and 404 educated (academic standard $\geq$ FSLC: First School Living Certificate); from purchasing power: 921 poor people and 210 riches [annual income < 370 US\$ (World Bank)]; from religion : 738 animists, 313 Christians and 80 Muslims; from sex : 394 men and 737 women; from profession : 70 traditional healers, 10 ethnobotanists or botanists, 05 physicians, 07 nurses, 397 housewives, 502 ethnoveterinarians-farmers, 37 cattle breeders, 21 hunters, 20 organic chemistry, 11 physiologists, 06 pharmacists, 25 sellers, 06 shepherds and 14 others; from familial situation: 1046, matrimonial status: 42 bachelors et 43 widows and widowers; from age brackets : 91 age between 30 and 40 years, 327 age between 41 and 50, 349 age between 51 and 60, 210 age between 61 and 70, 114 age between 71 and 80 , and 40 are between 80 and 90 (Tsabang N. et al. 2015b); from socio-cultural groups and some European and Central Africa interviewees (table 1 , table 2 and table 3 ); from 3 principal phytogeographic regions (coastal dense humid rain forests, continental dense humid rain forest and soudano-zambesian savannahs (carte 1)

\section{Identification of recorded plants}

The ethnobotanical survey carrying out in these units, beside interviewees selected in different tribes, may engender several plants (table 1, table 2 and table 3 ).

The table 1 shows the presence of Bamileke and Ewondo respectively outside West and Centre regions which is their actual territory. They are 
installed in Mungo (Littoral region) after the colonial obliged works. They become pioneers or employees of industrial plantations. Now they are definitively dwelled in the Mungo division.

The table 2 reveals again the presence of $\mathrm{Ba}$ kola Pygmies. They are dispersed in Bipindi subdivision in the first phytogeographic region and in Lolodorf subdivision in the second phytogeographic region. Kaka which are principally found in the East region of Cameroon have a small group in Ndian division of the South West region. In this phytogeographic region Ewondo is the most important group visited following by Bamileke. Bassa are dwelled inside the two first phytogeographic regions.

A total of 58 sociocultural groups (composed by 16 in coastal rain forests phytogeographic region, 14 in continental rain forests phytogeographic region, 23 in guinian and soudano-zambezian savannahs region were explored during the interwiews.

This sample of interviewees presents all the characteristics susceptible to provide reliable information and to promote the screening of many diabetic and hypertensive patients and plants used. Two categories of patients and their treatments were recorded.

Suspected or indirect patients: these are patients who are treated by traditional healers based on signs, symptoms and/or complications of diabetes and/or arterial hypertension that they develop. Their treatment was called suspected or indirect treatments.

Convincing or direct patients: these are patients identified previously by medical doctors who often use plants in familial medication. Their treatment was called potential treatment.

Self familial treatment: it is the treatment of patients by themselves or by family's members, from medicinal plants of familial patrimony or popular medicine. Two types of plants were identified:

Suspected or indirect plants: these are plants used by both traditional healers and to fight against at least 3 signs, 3 symptoms and/or 3 complications of the two pathologies. The pharmaceutical preparations derived from these plants are called suspected or indirect recipes.

Usual or direct plants: these are plants that are indicated by patients or traditional medicine practitioners as antidiabetic and/or antihypertensive. The ethnopharmaceutical preparations derived from these plants are called usual or direct recipes.

\section{Results and discussion \\ Choices of therapeutic resorts}

The different preferable therapeutic resorts of diabetes and hypertension treatment are grouped in 3 following principal set:

- Traditional medicine that is represented by self herbal medication which is the utilization of plants known in the family; consultation of traditional healers and sequential or simultaneous self herbal medication and consultation of traditional healers

- Conventional medicine represented by consultation of medical doctors; consultation of medical doctors and self-medication (use of manufactured drugs without medical prescription) and self-medication - Mixed or combined resorts: represented by consultation of medical doctors and self herbal medication; self herbal medication and self-medication; traditional healers and consultation of medical doctors; traditional healers, self herbal medication and consultation of medical doctors and self herbal medication, self medication and consultation of medical doctors. Table 4 presents the different percentages of the interviewees per treatment preferable resort.

\section{Statistical analysis}

\section{Comparison between the three types of resorts}

The number of interviewees who have preferred the mixed traditional and conventional medicine, the pure traditional medicine and the pure conventional medicine resorts for diabetes and arterial hypertension's treatment are respectively 666,438 and 27

If the three types of interviewees have the same chance to be met during the survey, there is equal probability: $p=q=t=1 / 3$. The three types 
of interviewees form each a trinomial distribution. It was about to compare the observed percentage for each type of interviewees to hypothetic value. According to the hypothesis zero (no difference between the three types of interviewees) the three types of interviewees have the same chance to appear during the survey. In this case they have the same prevalence in the population. The variance of this probability is $\mathrm{V}=\mathrm{pqt} / \mathrm{n}$ with $\mathrm{n}=1131$ (total number of interviewees) $\mathrm{V}=$ $1 / 3 \times 1 / 3 / \times 1 / 3 / 1131=0,00003274715$. Standard error: false $=0,00572251$. The observed values are:

Mixed traditional and conventional medicine $=$ $\mathrm{a} / \mathrm{n} \pm$ false $=0,5889 \pm 0,0146 \quad \mathrm{a}=666$; Traditional medicine $=\mathrm{a} / \mathrm{n} \pm$ false $=0,3872 \pm$ $0,0145 \quad a=438$

Conventional medicine $=\mathrm{a} / \mathrm{n} \pm$ false $=0,0239 \pm$ $0,0045 \quad a=27$

The different observed gap of hypothetic value is:

$\begin{array}{lrr}0,3872-0,3333=0,0539 ; & 0,3333- \\ 0,0239=0,3094 & 0,5889-03333=0,2556 .\end{array}$

By definition, these gaps are 2.6 times superior to standard error; we concluded that there was a significant difference between these three groups of interviewees at $95 \%$. The interviewees who preferred mixed traditional and conventional medicine were dominant.

Until what limits the variations of each resorts can be put on the account of chance? The normal variable with zero mean or the unit standard deviation is $d=a / n-p$ : false. So for traditional medicine resort the unit standard deviation: $d=$ $\mathrm{a} / \mathrm{n}-\mathrm{p}: \mathrm{false}=33,2431$

For conventional medicine resort the unit standard deviation: $d=a / n-p$ : false $=22,0752$

Mixed traditional and conventional medicine resort variations: $d=a / n-p$ : false $=18,2323$

The confidence intervals for the true unknown proportion were: 404,7569 to 471,2431 for resort traditional medicine; 4,9248 to 49,0752 for resort conventional medicine and 647,767 to 684,232 for resort mixed traditional and conventional medicine, at $95 \%$ coefficient of security. The probability so that the observed proportions of interviewees' types remained in these intervals, if the survey began again in the same conditions, was more increased. This sample was widely representative for the three types of interviewees in Cameroonian's population. In the research of an efficacious resort of diabetes and/ or hypertension's treatment, the population practice simultaneously or sequentially all alternative resorts to medical doctor's action.

Do exist in the population a group which practices the contrary of the general tendency? To respond to this question, the similar analysis have permit to compare the diabetes and arterial hypertension treatment's resorts preferred by interviewees which are distributed in the following social groups:

- Illiterates, educated, poors, riches grouped in fig. 1 ;

- Pagans, Christians, Muslims in fig 2;

- Men and women (distribution per sex) in fig. 3;

- Town dwellers and villagers in fig. 4;

- Distribution of interviewees per age brackets in fig. 5;

- Diabetic and/or hypertensive condition in fig. 6;

- Matrimonial status (brides and grooms, bachelors and single women and widowers and widows) in fig. 7.

It emerges from this analysis that exist a significant difference between the resorts traditional medicine, conventional medicine and mixed medicine, preferred by interviewees of social groups, two by two compared. We conclude that excepted the brides and grooms, the bachelors and single women and the widows and widowers (Fig.7) who choice a little bit the pure traditional medicine, the practice of alternative modes of medical doctors' actions in the diabetes and/or arterial hypertension' treatment and their complications, is a general fact for all the social strata in Cameroon.

\section{Suspected or indirect patients recorded at the traditional healers'}

Nine three (93) suspected or indirect patients in total were recorded and distributed as 
follow: thirteen diabetics with hypertension patients (13), implying $13.98 \%$; fifty two diabetics (52), implying $55.91 \%$ and twenty eight hypertensive patients (28), implying $30.11 \%$ (table 1a)

Suspect or indirect plants used for suspect or indirect patients (suspected treatments)

Thirty-seven (37) suspected and/or indirect plants in total were recorded. They were distributed in function of three categories of patients: 12 among them $(32,42 \%)$ were separately used for the suspected treatment of suspected diabetic with hypertensive patients; 13 among them $(35,16 \%)$ were separately used for the suspected treatment of suspected diabetic patients and $12(32,42 \%)$ were separately used for the suspected treatment of suspected hypertensive suspected patients. Plants which improve the health condition of patients have attracted our attention.

Six recorded plants which improve the health condition of diabetics with hypertension patients possess the confirmed hypoglycemic and/or hypotensive properties according to previous pharmacological studies. Azadirachta indica, Morinda lucida, Ceiba pentandra, Allium cepa (Bep, 1986); Persea americana (Berhaut, 1975) and Catharanthus roseus (Bep, 1986) are these plants, with both hypoglycemic and hypotensive properties.

Seven recorded plants which improve qui the health state of diabetic patient have hypoglycemic properties or hypoglycemic molecules. These plants are Momordica charantia (Pousset, 1989); Rhizophora racemosa (Bep 1986); Albizia ferruginea, Albizia lebbek (Kerharo and Adam 1974) and (Barret et Kiefer, 1998); Spathodea campanulata (Niyonzima et al., 1993); Bridelia micrantha and Sclerocarya birrea (Bep, 1986).

Seven identified plants that improve the health state of hypertensive patients have hypotensive activities. These plants are: Holarrhena floribunda (Paris and Moyse, 1971); Funtumia elastica, Voacanga africana, Picralima nitida, Piper guineense and Rauvolfia vomitoria (Bep, 1986) and Albizia adianthifolia with the extract confirmed hypotensive (Kerharo and Dam, 1974).

Twenty of the ninety-three suspected patients represented by 10 diabetics, 7 hypertensive patients and 3 diabetics with hypertension, implying $21.50 \%$ were previously identified in hospitals, where they were hospitalized at least one time. The treatment of traditional healers that they received, have improved their health condition. Therefore they asserted to have regularly satisfaction. Then we decided to follow up diabetics, hypertensive patients and diabetic with hypertension patients who use plants, in self familial medication for confirming this statement. The selection of these patients is not based on the signs, symptoms and/or complications that they develop like previously for suspected or indirect patients' selection, but by a diagnostic of a physician before the treatment. They are confirmed patients.

\section{Clinical follow up of diabetics and/or hyper- tensive patients}

One hundred and six (106) diabetics, 66 hypertensive patients and 10 diabetics with hypertension patients, for a total of 182 identified patients have been followed (table $2 b$ ).

\section{Ethnopharmacological preparation of herbal remedies and ethnomedical administration}

* This mark before a recipe indicates that the recipe was used to improve the health condition of suspected or indirect diabetic with hypertension patients.

$>$ This mark before a recipe indicates that the recipe was used to improve the health condition of suspected or indirect diabetic patients.

- This mark before a recipe indicates that the recipe was used to improve the health condition of suspected or indirect hypertensive patients.

Plants and recipes recorded in the coastal dense humid rain forests (phytogeographic area 1)

1-Mucuna pruriens: Boil 0,2 g of seeds powder per $\mathrm{kg}$ of the body weight in $250 \mathrm{ml}$. Filter and drink the filtrate, repeat the operation times per day.

2-Phyllanthus niruri: Macerate $1 \mathrm{~g}$ of aerial parts per $\mathrm{kg}$ of the body weight, in 2 I of water, for 2 h. Drink $250 \mathrm{ml}$ of filtrate 3 times per day. The filtrate also serves as laxative with higher doses.

3-Phyllanthus amarus: Macerate $1 \mathrm{~g}$ of aerial parts per $\mathrm{kg}$ of body weight, in $2 \mathrm{I}$ of water, for 
$2 \mathrm{~h}$. Drink $250 \mathrm{ml}$ of filtrate 3 times per day. The filtrate also serves as laxative with higher doses.

4-Rhizophora racemosa : Boil $2 \mathrm{~g}$ of stem bark per $\mathrm{kg}$ of body weight, in $2 \mathrm{I}$ of water, for $15 \mathrm{mn}$. Drink $250 \mathrm{ml}$ of decoction, 3 times daily.

- 5-Catharanthus roseus: Infuse $40 \mathrm{~g}$ of leave and $40 \mathrm{~g}$ of fresh root in $1 \mathrm{I}$ of water, for $4 \mathrm{~h}$. Drink $250 \mathrm{ml}$ of filtrate, 3 times per day.

- 6-Rauvolfia vomitoria : Maintain in ebullition $1,5 \mathrm{~g}$ of root bark per $\mathrm{kg}$ of body weight in 2 । of water. Drink $250 \mathrm{ml}$ of decoction, 3 times per day. The strong doses and the prolonged use provokes gastric ulcer (Bep, 1986).

Plants and recipes recorded in the continental dense humid rain forests (phytogeographic area 2)

7-Vernonia glabra: Clean and cut $100 \mathrm{~g}$ of rhizome, add to that $3 \mathrm{I}$ of water. Maintain in ebullition, for $30 \mathrm{mn}$. Filter and drink $250 \mathrm{ml}$ of filtrate, 4 times per day.

8-Momordica charantia: Boil $2 \mathrm{~g}$ per $\mathrm{Kg}$ body weight of stem, leaves, flower and fruit powder in 2 I of water. Drink a teaspoon of herbal tea, Drink $300 \mathrm{ml}$ of filtrate 3 times daily. The strong doses are toxic. Pregnant women must avoid taking this preparation (Arvigo and Balick, 1998).

9-Anacardium occidentale : Macerate $50 \mathrm{~g}$ of fresh leaves previously crumpled and $50 \mathrm{~g}$ of powder in 2 I of water, add $250 \mathrm{ml}$ of juice of false fruit. Drink 3 times per day, $250 \mathrm{ml}$ of filtrate.

* 10-Persea Americana: infuse 1g of young leaves and bud per $\mathrm{kg}$ of body weight, in $2 \mathrm{I}$ of water. Drink $250 \mathrm{ml}$ of filtrate, 3 times per day, for 7 days.

11-Pterocarpus osun : Boil $100 \mathrm{~g}$ of stem bark and $100 \mathrm{~g}$ of wood in $4 \mathrm{I}$ of water, for $30 \mathrm{mn}$. Drink $250 \mathrm{ml}$ of filtrate every $6 \mathrm{~h}$, for 5 days.

* 12-Allium cepa: Infuse $200 \mathrm{~g}$ of cut bulb in $2 \mathrm{I}$ of water. Drink $250 \mathrm{ml}$ of filtrate every $6 \mathrm{~h}$.

13-Momordica foetida: Macerate $80 \mathrm{~g}$ of fresh leaves in $2 \mathrm{I}$ of water, then use the filtrate to rup the painful muscles and numbed feet. Drink 250 $\mathrm{ml}$ of decoction, 2 times per day, for 7 days.
$300 \mathrm{~g}$ of stem bark in $4 \mathrm{I}$ of water, for $30 \mathrm{mn}$. Drink $250 \mathrm{ml}$ of decoction, every $6 \mathrm{~h}$, for 5 days. The excess and the prolonged use can provoke vomiting and purgation.

15-Albizia ferruginea : Boil $200 \mathrm{~g}$ of root bark and $100 \mathrm{~g}$ of wood in $4 \mathrm{I}$ of water, for $30 \mathrm{mn}$. Drink $250 \mathrm{ml}$ of filtrate 2 times per day, for 5 days. The strong doses and the prolonged usage are toxic.

- 16-Albizia adianthifolia : Maintain in ebullition $100 \mathrm{~g}$ of stem bark in 2 I of water, for $10 \mathrm{mn}$. Drink $250 \mathrm{ml}$ of decoction, 2 times per day $6 \mathrm{~h}$, for 5 days.

17-Aloe buettneri: Macerate $200 \mathrm{~g}$ of leaves, in 2 I of water. Drink deliberately the filtrate controlling the glycemia and the blood pressure.

18-Aloe barteri: Macerate $200 \mathrm{~g}$ of leaves, in $2 \mathrm{I}$ of water. Drink deliberately the filtrate controlling the glycemia and the blood pressure.

19-Spathodea campanulata: Drink orally 250 $\mathrm{ml}, 3$ times per day, a $1 \mathrm{~g}$ herbal tea of stem bark powder per body weight, prepared in $2 \mathrm{I}$ of water

- 20-Morinda lucida : Boil 1,5 g per kg of body weight in $4 \mathrm{I}$ of water, for $30 \mathrm{mn}$. Drink $250 \mathrm{ml}$ every $6 \mathrm{~h}$.

21-Solanum melongena and Capsicum frutescens : Cook fruits of garden egg (Solanum melongena) with a little salt or with or without pepper (Capsicum frutescens). Sift and drink the filtrate called Medip-me-zon in Ewondo and in Boulou, in the morning instead of coffee tea.

- 22-Holarrhena floribunda: Boil 4 tablespoons of stem bark powder in 1,5 I of water, for $15 \mathrm{mn}$. Drink $250 \mathrm{ml}$ of decoction, morning and evening, for 7 days.

23-Funtumia elastica: Boil $150 \mathrm{~g}$ of leaves in 2 I of water, for $30 \mathrm{mn}$. Drink $250 \mathrm{ml}$ of decoction every $6 \mathrm{~h}$.

24-Laportea ovalifolia: Boil $100 \mathrm{~g}$ of aerial parts in $6 \mathrm{I}$ of water, for $15 \mathrm{mn}$. Drink $250 \mathrm{ml}$ of decoction, 3 times per day controlling the glycemia.

- 25-Voacanga africana: Boil $200 \mathrm{~g}$ of bark in 4 I of water. Drink $250 \mathrm{ml}$ of decoction, 3 times per day. 
ly. It is very bitter.

Plants and recipes recorded in Guinean and Soudano-Zambesian savannahs

27-Vernonia glabra : Clean and cut $100 \mathrm{~g}$ of rhizome, add to that $3 \mathrm{I}$ of water. Maintain in ebullition, for $30 \mathrm{mn}$. Filter and drink $250 \mathrm{ml}$ of filtrate, 4 times per day.

28-Brassica oleracea and Citrus grandis: Pound $1 \mathrm{~g}$ of leaves of cabbage (Brassica oleracea), per $\mathrm{kg}$ of body weight and filtrate; add to the filtrate an equal volume of grapefruit juice (Citrus grandis.) homogenize and drink the filtrate controlling the glycemia.

> 29-Sclerocarya birrea: Boil $250 \mathrm{~g}$ of stem bark or $100 \mathrm{~g}$ of leaves in $4 \mathrm{l}$ water. Drink $250 \mathrm{ml}$ of decoction, 3 times per day.

* 30-Azadirachta indica: Boil for $40 \mathrm{mn}, 50 \mathrm{~g}$ of stem bark, $50 \mathrm{~g}$ of flower and $50 \mathrm{~g}$ of root in 4 I of water. Drink $250 \mathrm{ml}$ of decoction, 2 times per day, for 4 days.

* 31-Albizia lebbek : Boil for $20 \mathrm{mn}, 200 \mathrm{~g}$ of root bark, 50 in 4 I of water. Drink $250 \mathrm{ml}$ of filtrate, 2 times per day, for 4 days.

> 32-Bridelia ferruginea: Infuse for $6 \mathrm{~h}, 200 \mathrm{~g}$ of stem bark, in 4 I of water. Drink $250 \mathrm{ml}$ of filtrate, 3 times per day.

- 33-Piper capense: Boil $150 \mathrm{~g}$ of fresh leave in 3,5 I of water. Drink $250 \mathrm{ml}$ of decoction, 3 times per day.

\section{Conclusion}

In Cameroon three main resorts for treating diseases exist in general and in the particular case of diabetes and/or arterial hypertension the combination of traditional and conventional medicine was the most favorable therapeutic resort $(58,89 \%)$, following by pure traditional medicine $(38,72 \%)$ and pure conventional medicine $(2,39 \%)$. These main resorts present manifold variances in many social groups including: self herbal medication and consultation of medical doctors (33,08\%); traditional healers, self herbal medication and consultation of medical doctors $(22,64 \%)$; Self herbal medication and consultation of traditional healers $(21,75 \%)$; Self herbal medication $(16,62 \%)$; consultation of traditional healers and consultation of medical doctors
$(I 1,94)$; Consultation of medical doctor $(2,39 \%)$. The percentages in brackets correspond to the proportion of interviewees recorded. A marked improvement was registered in $21,50 \%$, of patients using suspected antidiabetic and/or antihypertensive plants. The interviewees who preferred traditional medicine know more available and efficacious medicinal plants. Therefore with their aid 33 plants (6 in coastal dense humid rain forests; 20 in continental dense humid rain forests and 7 in Guinean and Soudano-Zambesian savannahs) which relieve the health condition of some diabetic and/or hypertensive suspected or indirect and confirmed patients were recorded. Their ecological distribution is favorable to their availability in Cameroon. The most important of these plants that include Azadirachta indica, Momordica charantia, Phyllanthus amarus, Phyllanthus niruri, Laportea ovalifolia, Ceiba pentandra, Allium cepa, Persea americana and Catharanthus roseus relieve the followed up diabetic with hypertension patients. These plants revealed interesting for the potential management of diabetes and hypertension. Meanwhile the recorded plants needed to be detailed investigated for their chemical and pharmacological properties necessary for drugs discovery.

\section{Acknowledgments}

Thanks are expressed to health tradipractioners, householders and other interviewees met in the field which have participated and collaborated to the realization of this work, to Bioresources Development and Conservation Programme-Cameroon (BDCP-C) for the training courses that we receive on field ethnobiology and to Professor Koueke Paul, retired Professor of Faculty of Medicine and Biomedical Sciences, University of Yaoundé 1 for precious help in the comprehension of pharmacological terms.

\section{Abbreviations}

SHM: Self-herbal medication

SHMTH: Sequential or simultaneous self herbal medication and consultation of traditional healers

CMSM: Conventional medicine (CM) and self-medication (SM) (use of manufactured drugs without medical prescription)

CMDSHM: Consultation of medical doctors and self herbal 
medication

SHMSM: Self herbal medication and self-medication

CTHMD: Consultation of traditional healers and consultation of medical doctors

CTHSHMCMD: Consultation of traditional healers, self herbal medication and consultation of medical doctors

SHMSMCMD: self herbal medication, self medication and consultation of medical doctors

\section{References}

Barrett B. and Kiefer D. (1996). Ethnomedical, Biological and Clinical support for medicinal Plant Use on Nicaragual's Atlantic Coast. Journal of Herbs, Spices and Medicinal Plants, 4 (3): 77-108.

Bep O B. (1986), Medicinal plants in Tropical West-Africa, Cambridge University Press, Cambridge, NewYork, new - Romelbourne, Sedneychelle, 375 p.

Berhaut J. (1975). Flore illustrée du Sénégal, Dicotylédones, Ficoidées à Mimosacées. Gouvernement du Sénégal, Ministère du développement rural et de l'Hydraulique. Direction des eaux et forêts Dakar, Tome $4: 575 \mathrm{p}$.

Kerharo J et Adam G., (1974). La pharmacopée Sénégalaise traditionnelle. Plantes médicinales et toxiques. Editions Vigot frère, Paris, 1011 p.

Lokondo Mozouloua Dieudonné (2004) Traitement traditionnels de 150 maladies à base de plantes. Pharm. Méd. Trad. Afr. Vol.13, pp.III-116

Niyonzima G., Scarpé S., Van Beeck L., Vlietinck A. J.,. Laekeman G. M and. Metz T (1993), Hypoglycaemic activity of Spathodea campanulata stem bark decoction in mice. Phytotherapy research, Vol.7, pp. 64-67

Paris R. and MOYSE H. (1971), Précis de matières médicales, collection de précis de pharmacie, Pharmacognosie spéciale, dicotylédone (suite) gamopétales, Masson et Cie, Editeurs Paris Vie, Tome 3, $509 \mathrm{p}$.

Pousset J. L., (1989). Plantes Médicinales Africaines. Utilisation pratique. TOME I. Ellipses,

Edition Marketing, Paris, 170 p.

Priya Shetty (2010) Place de la médecine traditionnelle dans le système de santé: Faits et chiffres. Sc Dev Net Rapprocher la science et le développement

Regroupement québécois des maladies orphelines. Pour un meilleur accès aux traitements pour les mal- adies rares. Une question d'équité. Fiche technique en préparation du dîner-causerie sur l'accès aux traitements pour les maladies rares, 21 février 2014. http://www.rqmo.org/PDF/Document_preparatoire_ diner-conference_21_fevrier.pd

UN Economic and Social Council (2009) Potential of traditional medicine should be fostered, Economic and Social Council President tells panel on attaining Millennium Development Goals in public health.

Tsabang, N. Yedjou, C. Tsambang Djeufack, W .L Tiabo Tchinda A., Donfagsiteli Tchinda, N. Agbor Agbor G., Tchounwou P. B. and Nkongmeneck A. B. (2015a), Treatment of diabetes and/or hypertension using medicinal plants in Cameroon, Medicinal \& Aromatic Journal $5 \mathrm{p}$.

Tsabang Nole, WL Tsambang Djeufack, Armel Nouboudem Tedjou, Alain Bernard Dongmo, Somwa Denis Gabriel Agbor Agbor and Aloys Bernard Nkongmeneck (2015b). Ethnopharmacological surveys' methodologies for medicinal plants uses discovery and environmental threatens on recorded plants from indigenous knowledge in Cameroon. Global Journal of Medicinal Plants Research 12-22 p.

Tsabang, N. (2008). Etude ethnobotanique des plantes à vertus antidiabetiques et/et antihypertensives au Cameroun. Thèse de Doctorat/PhD. Université de Yaoundé I 318 p.

WHO, (2007) Country Cooperation Strategy 20062011, India: Supplement on traditional medicine WHO Country Office for India, New Delhi

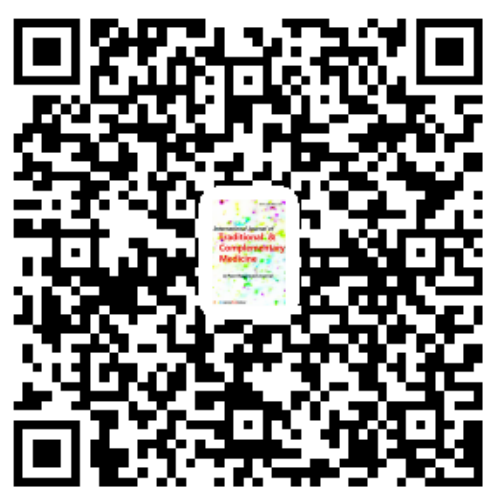


Nole et al., IJTCM, 2016; Vol. 1(4): 0045-0059

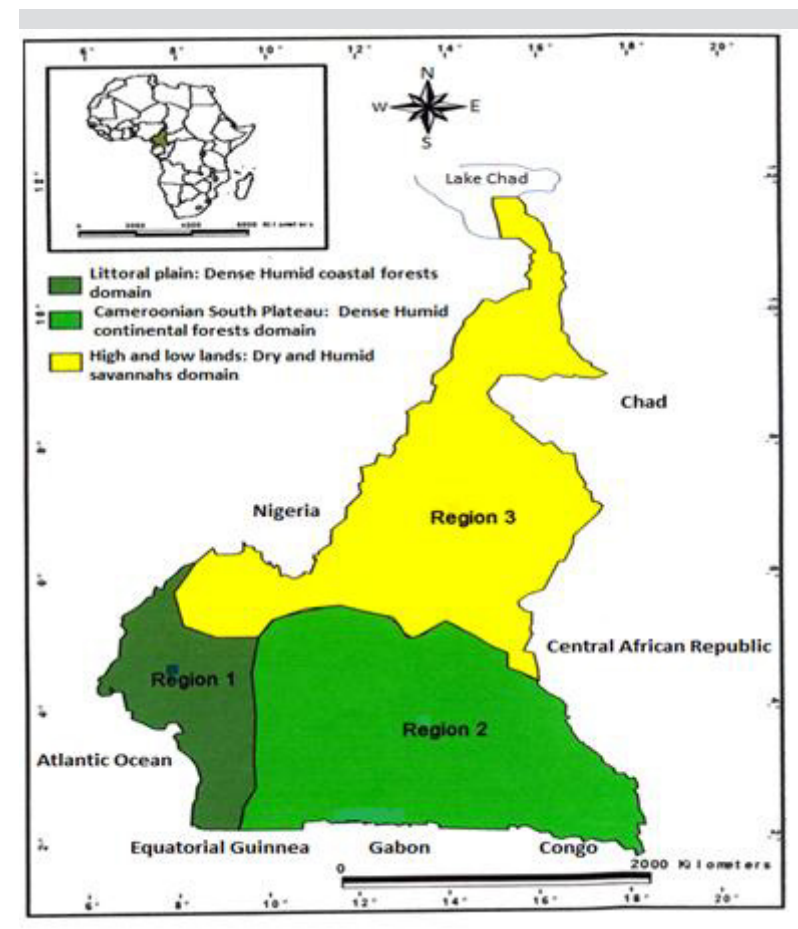

Table 1: Distribution of interviewees by socio-cultural groups in coastal dense humid rain forests

\begin{tabular}{|l|l|}
\hline Socio-cultural groups & $\begin{array}{l}\text { Number of interview- } \\
\text { ees }\end{array}$ \\
\hline Abo & 5 \\
\hline Anyang & 8 \\
\hline Bakoko & 13 \\
\hline Bakossi & 16 \\
\hline Bakweri & 12 \\
\hline Balong & 16 \\
\hline Bamileke & 25 \\
\hline Bangwa & 12 \\
\hline Bassa & 31 \\
\hline Batanga & 8 \\
\hline Bayangi & 18 \\
\hline Douala & 16 \\
\hline Ejagham & 10 \\
\hline Ewondo & 8 \\
\hline Korup & 6 \\
\hline Malimba & 17 \\
\hline Mbo & 31 \\
\hline Bakola Pygmies & 5 \\
\hline Nyassa & 8 \\
\hline Oroko & 19 \\
\hline Europeans and others Af- & 9 \\
\hline ricans met & 293 \\
\hline Total & 9 \\
\hline
\end{tabular}

Fig. 1: Principal phytogeographic areas of Cameroon (Tsabang N., 2008)

Table 1a : Distribution of suspected or indirect patients and suspected or indirect plants used for their treatment by traditional healers.

Diab : Diabetics. Hyp : Hypertensive patients. Diab-Hyp : Diabetic with Hypertension patients

\begin{tabular}{|l|l|l|l|l|l|l|l|l|}
\hline \multicolumn{8}{|l|}{ Suspected or indirect patients } & \multicolumn{4}{l|}{ Suspect or indirects plants } \\
\cline { 2 - 7 } \\
ber
\end{tabular}




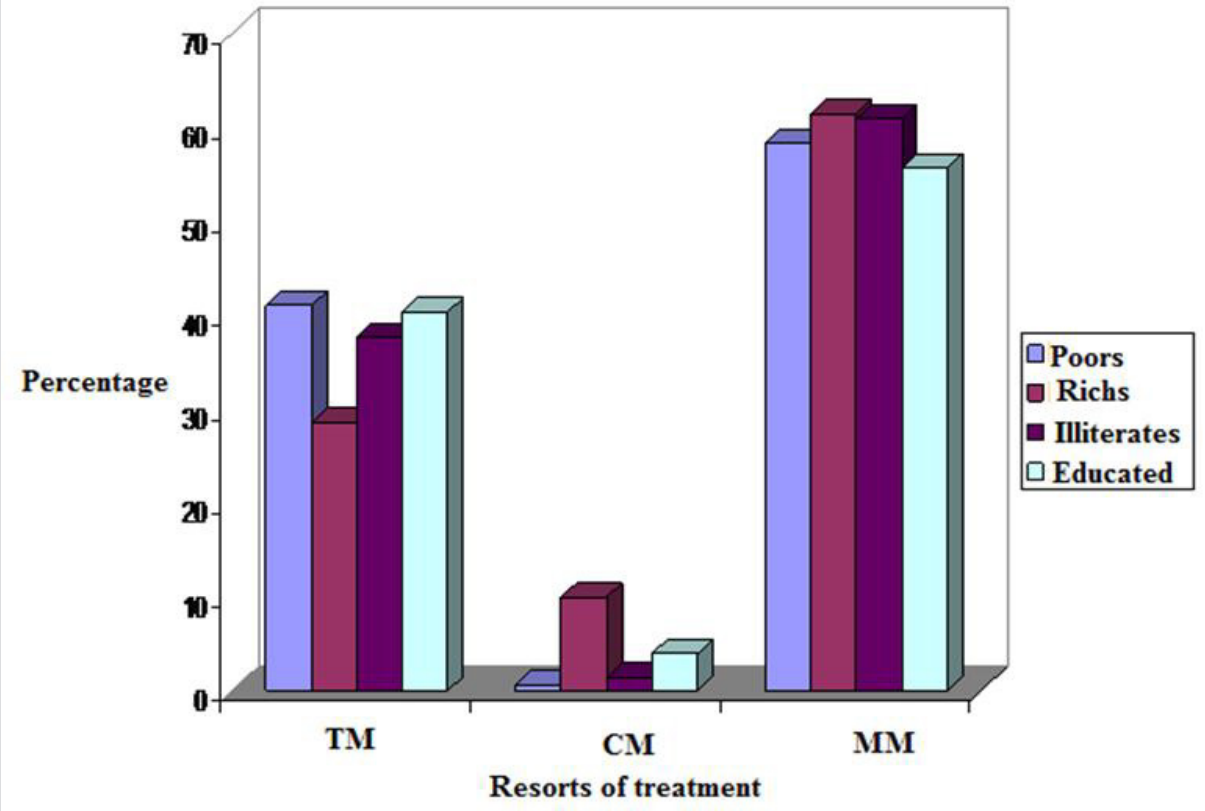

Legend: TM: Traditional medicine; CM: Conventional medicine; MM: Mixed medicine

Fig. 1b: Preferred resorts of treatment' distribution in function of standard of life and academic standard

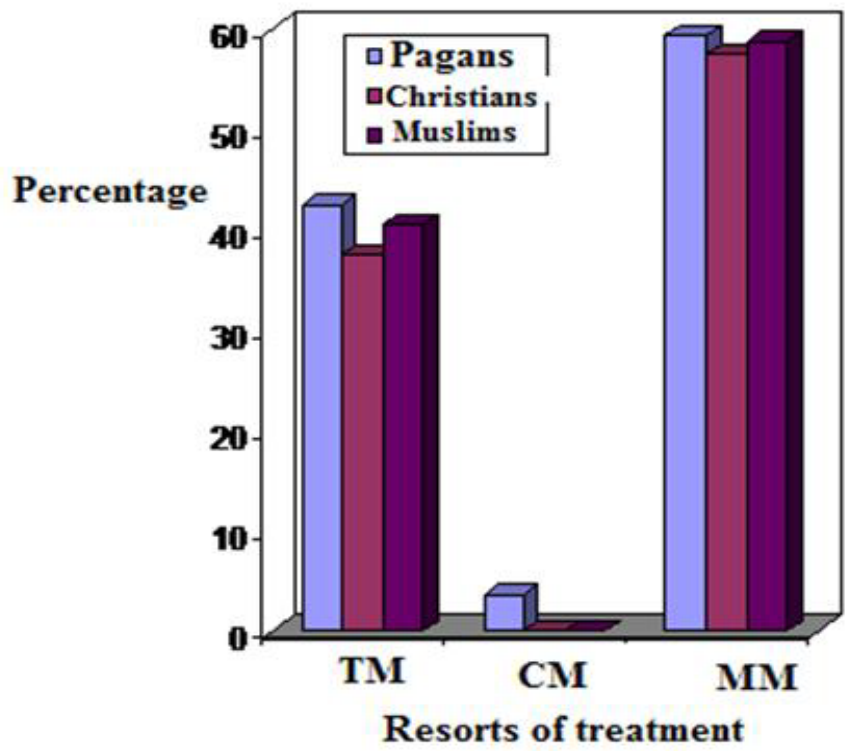

Legend: TM: Traditional medicine; CM: Conventional medicine; MM: Mixed medicine

Fig. 2. Preferred resorts of treatment' distribution in function of religion 


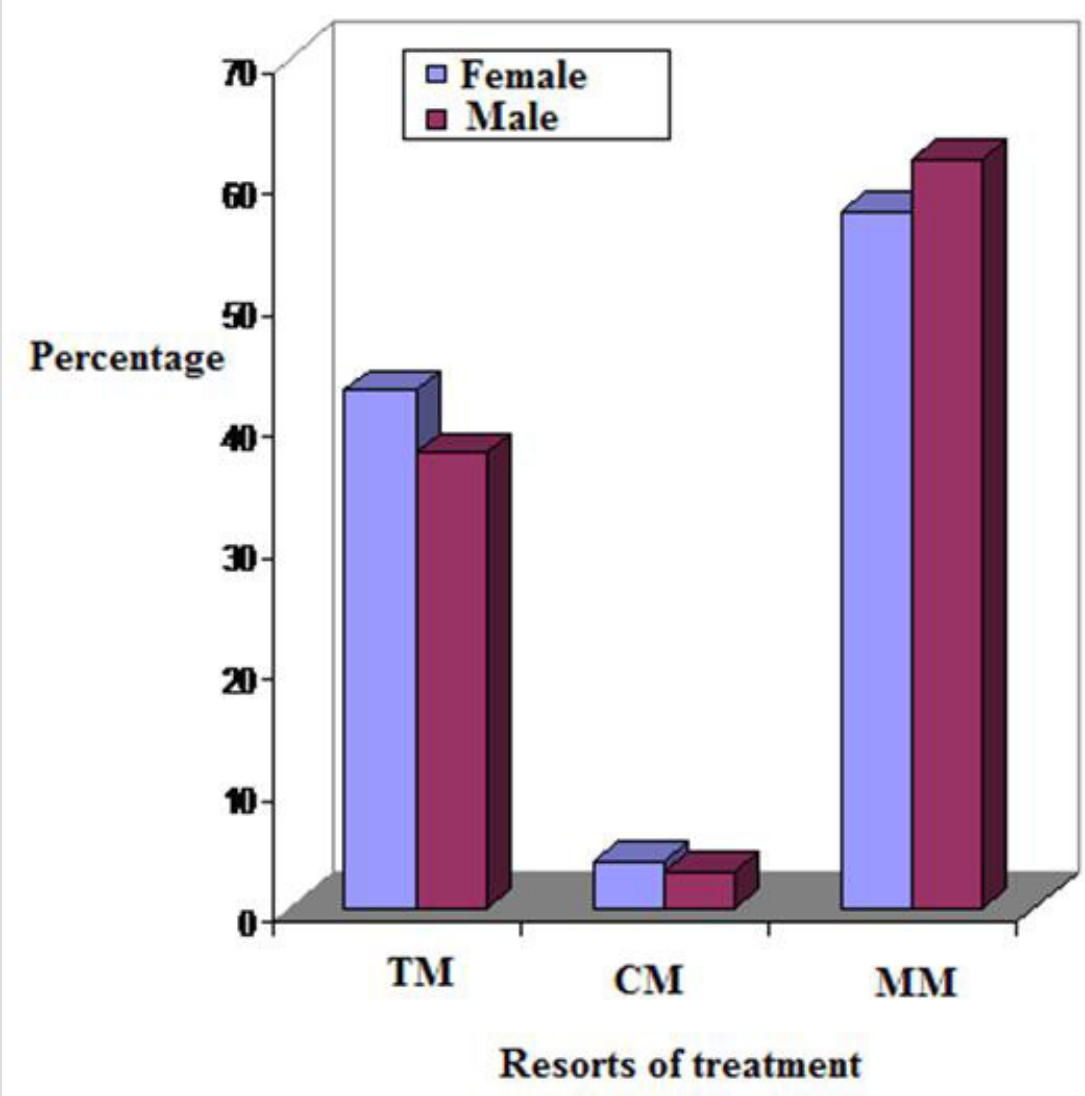

Legend: TM: Traditional medicine; CM: Conventional medicine; MM: Mixed medicine

Fig. 3: Preferred resorts of treatment' distribution in function of sex

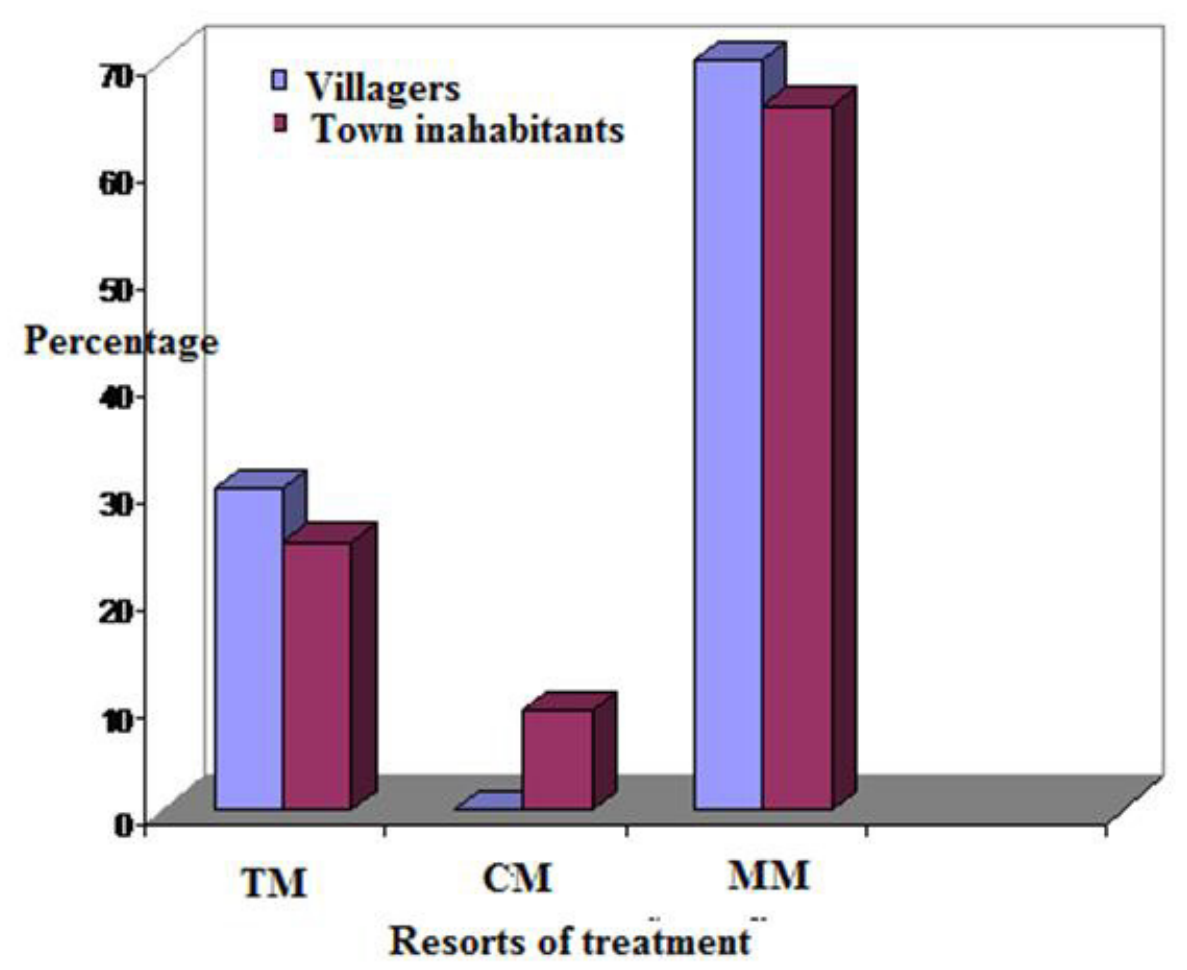

Legend: TM: Traditional medicine; CM: Conventional medicine; MM: Mixed medicine

Fig. 4: Preferred resorts of treatment' distribution in function of geographic residence 


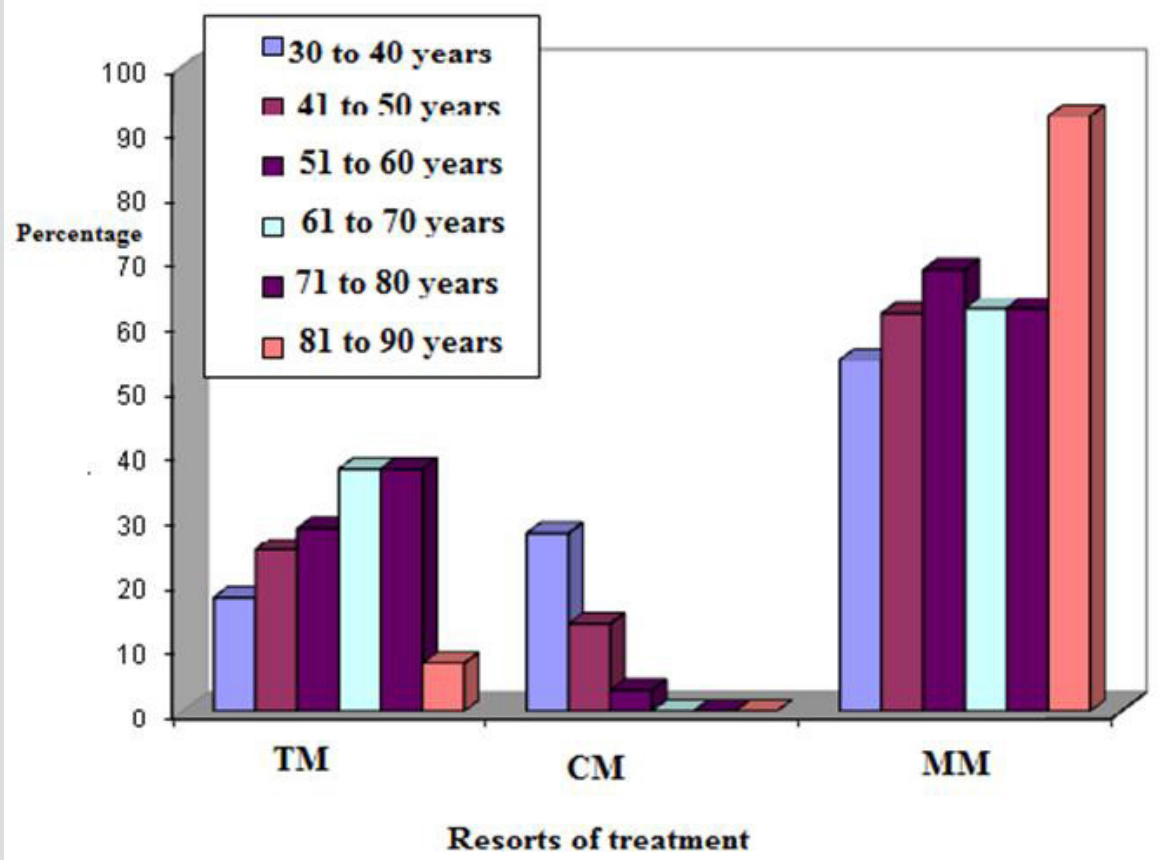

Legend: TM: Traditional medicine; CM: Conventional medicine; MM: Mixed medicine

Fig. 5: Preferred resorts of treatment' distribution in function of brackets

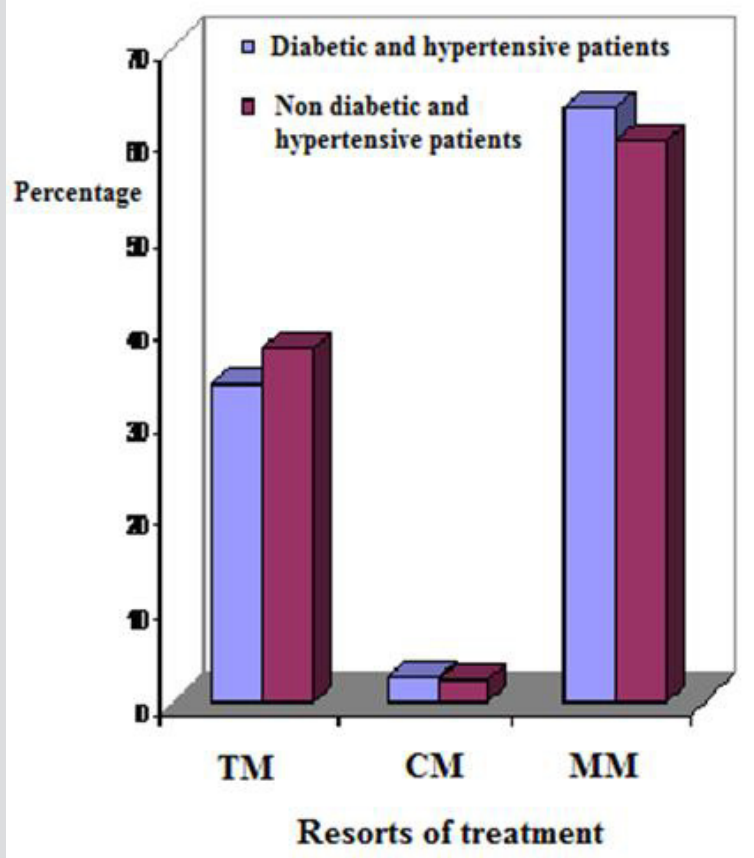

Legend: TM: Traditional medicine; CM: Conventional medicine; MM: Mixed medicine

Fig. 6: Preferred resorts of treatment' distribution in function of diabetic and/or hypertensive condition 


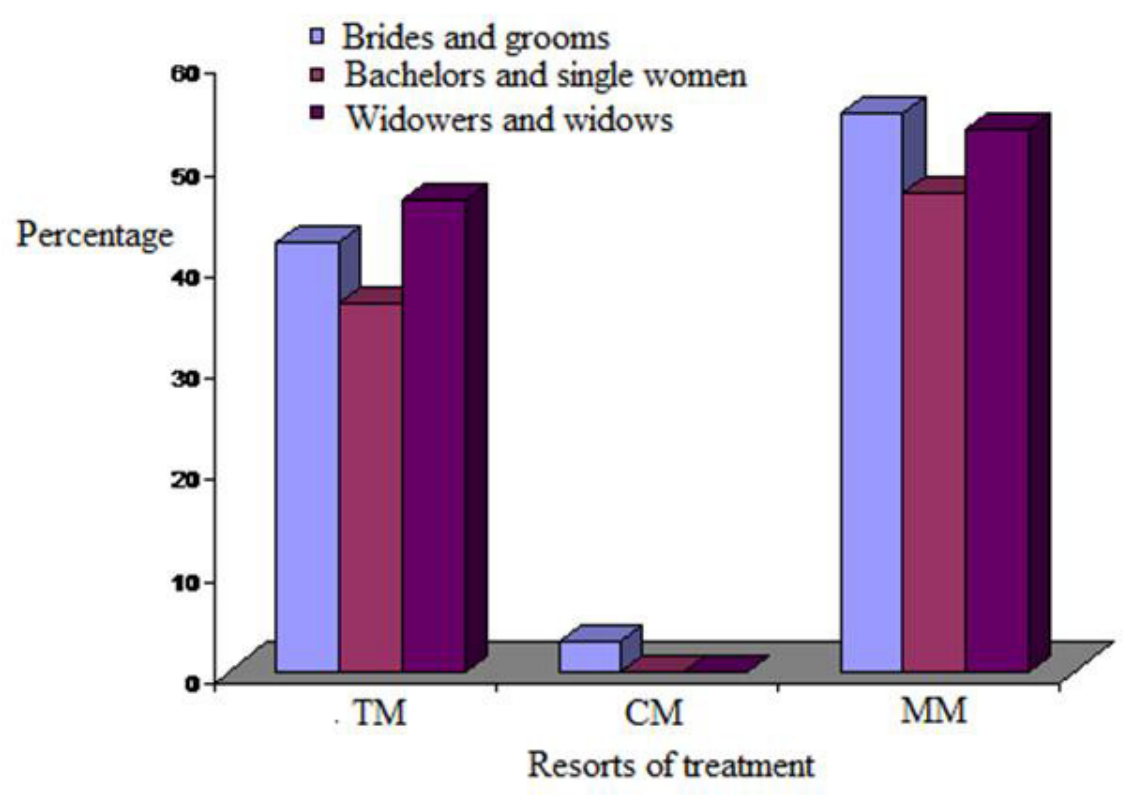

Legend: TM: Traditional medicine; CM: Conventional medicine; MM: Mixed medicine

Fig. 7: Preferred resorts of treatment' distribution in function of matrimonial status

Table 2: Distribution of interviewees' socio-cultural groups in continental rain forests of Cameroon

\begin{tabular}{|l|l|}
\hline Sociocultural groups & Number of interviewees \\
\hline Badjoue & 11 \\
\hline Bafia & 8 \\
\hline Bamileke & 34 \\
\hline Bamvele & 2 \\
\hline Banen & 10 \\
\hline Bassa & 16 \\
\hline Baya & 8 \\
\hline Bobilis & 5 \\
\hline Boulou & 26 \\
\hline Ewondo & 60 \\
\hline Eton & 23 \\
\hline Fang & 17 \\
\hline Kaka & 6 \\
\hline Makae & 7 \\
\hline Mvele & 2 \\
\hline Ngouba & 8 \\
\hline Baka Pygmies & 12 \\
\hline Bakola Pygmies & 12 \\
\hline Yambassa & 9 \\
\hline Swisszerland (trainee student) & 1 \\
\hline Total & 277 \\
\hline
\end{tabular}


Table 2b: Distribution of diabetics and/or hypertensive patients previously diagnosed in hospitals NIDD: Non insulinodependent diabetes; IDD: Insulinodependent diabetes; EHT: essential hypertension; SHT: Secondary hypertension.

\begin{tabular}{|c|c|c|c|c|c|c|}
\hline \multirow{2}{*}{$\begin{array}{l}\text { Sex and clinical state of } \\
\text { Patients }\end{array}$} & \multicolumn{2}{|c|}{ Diabetics } & \multicolumn{2}{|c|}{$\begin{array}{l}\text { Hypertension } \\
\text { Patients }\end{array}$} & \multicolumn{2}{|c|}{$\begin{array}{l}\text { Diabetics with hyperten- } \\
\text { sion patients }\end{array}$} \\
\hline & DNID & DID & THE & HTS & DNID-HTS & DNID- THE \\
\hline Men & 47 & 18 & 48 & 24 & 03 & 01 \\
\hline Women & 28 & 21 & 48 & 37 & 04 & 02 \\
\hline Total & 75 & 39 & 96 & 61 & 07 & 03 \\
\hline Total per type of diseases & 85 & 39 & 99 & 68 & & \\
\hline Clinical followed up patients patients & 70 & 36 & 10 & 56 & 07 & 03 \\
\hline Total per type of patients & \multicolumn{2}{|c|}{106} & \multicolumn{2}{|c|}{66} & \multicolumn{2}{|c|}{10} \\
\hline
\end{tabular}

Table 3: Distribution of interviewees' socio-cultural groups in soudano-zambezian and guinian savannahs zones

\begin{tabular}{|c|c|}
\hline Socio-cultural groups & Number of interviewees \\
\hline Arabes -choa & 1 \\
\hline Bafut & 8 \\
\hline Bali & 12 \\
\hline Bamileke* & 201 \\
\hline Bamoun & 18 \\
\hline Baya & 37 \\
\hline Bororo & 8 \\
\hline Dourou & 23 \\
\hline Foulbe & 24 \\
\hline Haoussa & 17 \\
\hline Kom & 82 \\
\hline Kotoko & 7 \\
\hline Mafa & 2 \\
\hline Massa & 5 \\
\hline Matakam & 4 \\
\hline Moundang & 4 \\
\hline Mbum & 10 \\
\hline Mousgoum & 2 \\
\hline Nso & 40 \\
\hline Tikar & 15 \\
\hline Toupouri & 7 \\
\hline Fali & 3 \\
\hline Widekam & 19 \\
\hline Wum & 11 \\
\hline Originer of Europ met & 1 \\
\hline Total & 561 \\
\hline
\end{tabular}


Table 4: Interviewees and preferred resorts of treatment

\begin{tabular}{|c|c|c|c|c|c|c|c|c|c|c|c|c|}
\hline \multirow[b]{3}{*}{ Number } & \multicolumn{3}{|c|}{$\begin{array}{l}\text { Traditional } \\
\text { medicine resorts }\end{array}$} & \multicolumn{3}{|c|}{$\begin{array}{l}\text { Conventional } \\
\text { medicine resorts }\end{array}$} & \multicolumn{5}{|c|}{ Mixed resorts } & \multirow[t]{2}{*}{ N I } \\
\hline & SHM & $\underset{\substack{I \\
\text { ড }}}{\stackrel{I}{\leftrightarrows}}$ & CTH & CMD & SM & $\sum_{n}^{0}$ & $\sum_{\substack{n \\
n}}$ & 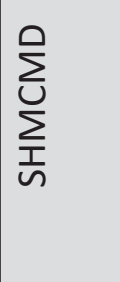 & $\sum_{\substack{0 \\
\text { บ }}}^{0}$ & 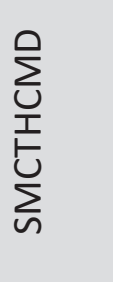 & 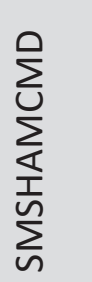 & \\
\hline & 188 & 246 & 04 & 27 & & & 12 & 374 & 22 & 256 & 02 & 1131 \\
\hline$\%$ per resort & 16,62 & 21,75 & 0,35 & 2,39 & & & 1,06 & 33,08 & 1,94 & 22,64 & 0,17 & 100 \\
\hline $\begin{array}{l}\% \text { per type of } \\
\text { medicine }\end{array}$ & \multicolumn{3}{|l|}{38,72} & \multicolumn{3}{|l|}{2,39} & \multicolumn{5}{|c|}{58,89} & 100 \\
\hline
\end{tabular}

SHM: Self herbal medication; SHM : Self herbal medication and consultation of traditional healers; CTP : Consultation of traditional healers; CMD : Consultation of medical doctor; SM : Self medication; SMCMD: Self medication and consultation of medical doctors: SHMSM: Self herbal medication and Self medication; SMCMD: Self medication and consultation of medical doctors; CTHCMD: Consultation of traditional healers and consultation of medical doctors; Self herbal medication; SHMSM: Self herbal medication, self medication and consultation of medical doctors; NI : Number of interviewees. 